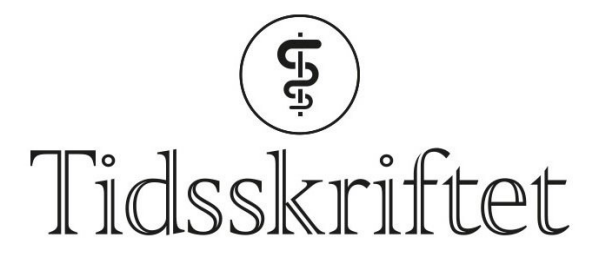

DEN NORSKE LEGEFORENING

\title{
Hyppig antibiotikabruk ved diaré i Afrika
}

FRA ANDRE TIDSSKRIFTER

KRISTOFFER BRODWALL

Barne- og ungdomsklinikken Haukeland universitetssykehus

I Afrika sør for Sahara blir nesten hvert fjerde barn under fem år med ikke-blodig diaré behandlet med antibiotika.

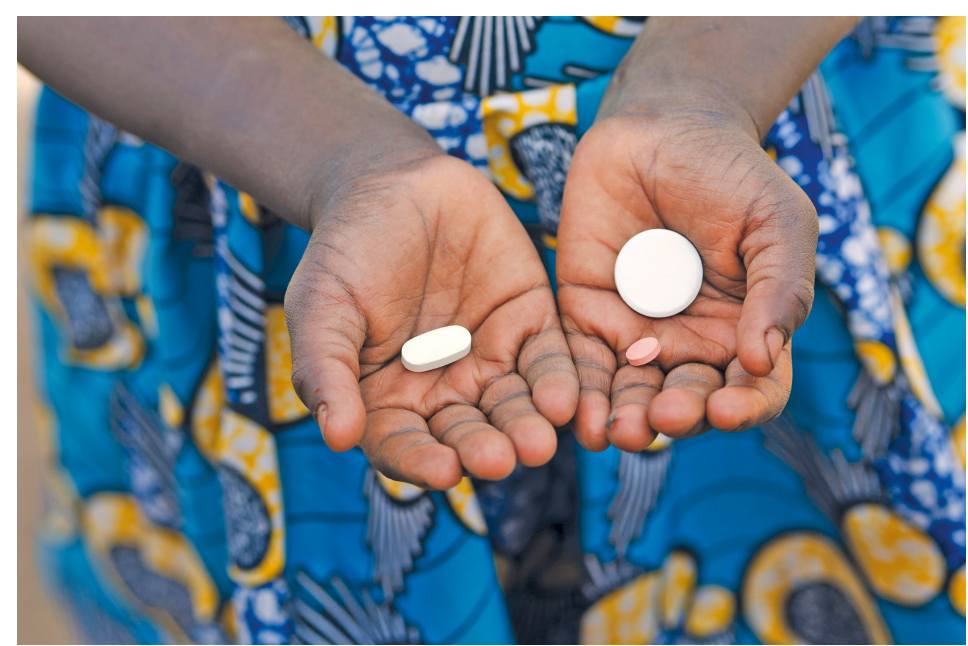

Illustrasjonsfoto: Riccardo Lennart Niels Mayer/iStock

Diarésykdommer rammer mange barn og forårsaker over $1 \frac{1}{2}$ million årlige dødsfall globalt, de fleste i Afrika. Anbefalt behandling er enkel: rehydrering, sinktilskudd og ernæringsstøtte. Antibiotika anbefales kun ved blodig diaré, mistanke om kolera eller sepsis. Uhensiktsmessig bruk av antibiotika kan forverre symptomene og gi økt resistens.

I en fersk studie tok man sikte på å estimere forekomsten av slik feilaktig behandling (1). Studien var en metaanalyse av opplysninger samlet inn ved helseunders $\varnothing$ kelser i perioden 2000-16 i zo land i Afrika sør for Sahara og omfattet nesten 300 ooo barn under fem år.

Samlet fikk 23 \% av barna med ikke-blodig diaré antibiotika. Andelen var lavest i Øst-Afrika, der $19 \%$ fikk antibiotika, og høyest i Sentral-Afrika, der $28 \%$ fikk antibiotika. Hyppigst ble antibiotika gitt i Republikken Kongo, der 6o \% fikk slik behandling.

Barnets alder og kjønn påvirket ikke sannsynligheten for å få antibiotika. Derimot ble antibiotika oftere gitt der pasientens foreldre tilhørte gruppen med høyest inntekt, der mor hadde lengre utdanning, og der pasienten bodde i et byområde. I tilfeller der offentlige eller 
private sykehus og klinikker hadde vært involvert i behandling, fikk 30-40 \% av barna antibiotika, mens bare 5-17\% av barna fikk antibiotika når en tradisjonell behandler eller ingen behandler hadde blitt oppsøkt.

Forfatterne nyanserer bildet ved å argumentere med at inntil $13 \%$ av tilfellene med ikkeblodig diaré kan skyldes Shigella eller enteroinvasiv E. coli, der antibiotika kan ha effekt. Men heller ikke ved slike infeksjoner er antibiotika anbefalt. Studien viser at det totale forbruket av antibiotika ved diaré i Afrika sør for Sahara er altfor høyt.

\section{LITTERATUR:}

1. Auta A, Ogbonna BO, Adewuyi EO et al. Prevalence and factors associated with the use of antibiotics in non-bloody diarrhoea in children under 5 years of age in sub-Saharan Africa. Arch Dis Child 2019; 104: 518-21. [PubMed][CrossRef]

Publisert: 23. august 2019. Tidsskr Nor Legeforen. DOI: 10.4045/tidsskr.19.0422

(C) Tidsskrift for Den norske legeforening 2020. Lastet ned fra tidsskriftet.no 